\title{
PROSES BERPIKIR ALJABAR SISWA MTS KELAS VIII MENURUT TAKSONOMI SOLO DITINJAU DARI PERBEDAAN GENDER
}

\author{
Lilia Sinta Wahyuniar ${ }^{1}$, Niska Shofia ${ }^{2}$, Siti Rochana ${ }^{3}$ \\ ${ }^{1,2,3}$ Pendidikan Matematika, Universitas Nusantara PGRI Kediri \\ E-mail: $\quad$ li2asint@gmail.com ${ }^{l)}$ \\ mail_niez@yahoo.co.id
shirofull65@gmail.com $\left.^{3}\right)$
}

Received 8 August 2018; Received in revised form 17 September 2018; Accepted 24 September 2018

\begin{abstract}
This study aims to describe the algebraic thinking process of grade VIII MTs students in solving algebraic problems based on Taksonomi Solo seen from gender differences in students with high mathematical abilities. The research was carried out in the eighth grade of Miftahul Huda MTs in Kediri Regency. The research subjects consisted of two students, namely women and men with high abilities. Subjects were chosen based on information from the teacher regarding mathematical abilities and the willingness and openness of the subject to be interviewed about the task of algebra problems. The results of the study showed that female students with high abilities fulfilled the indicators of algebraic thinking, namely finding certain tribes and generalizing the given patterns and understanding the role of variables as numbers that are known in algebraic form, equations and inequalities. Whereas male students with high abilities only fulfill the indicators of algebraic thinking, namely finding certain tribes in the given pattern.
\end{abstract}

Keywords: Algebra Thinking Processes; Taksonomi Solo; Gender.

\section{PENDAHULUAN}

Dalam mempelajari suatu hal, manusia pasti melakukan aktivitas berpikir dalam otaknya. Berpikir merupakan faktor penting dalam proses pembelajaran siswa. Memahami cara berpikir siswa adalah cara yang baik untuk mengajar karena membangun pengetahuan dari cara alami berpikir siswa, dapat mempermudah proses pemahaman. Menurut Tatag Yuli Eko Siswono dalam Saefudin (2011) proses berpikir adalah suatu proses yang dimulai dengan menerima data, mengolah dan menyimpannya dalam ingatan serta selanjutnya mengambil kembali dari ingatan saat dibutuhkan untuk pengolahan selanjutnya. Dalam ((Nafi'an, 2012); (Susandi \& Widyawati, 2017)) Proses berpikir merupakan proses yang digunakan seseorang dalam menerima informasi yang kemudian dari informasi tersebut di proses atau diolah untuk dicari kesimpulannya dan kesimpulan tersebut digunakan kembali untuk menyelesaikan masalah yang terkait untuk memecahkan masalah ingatan.

$\begin{array}{rlr}\text { Aljabar merupakan materi yang } \\ \text { dapat } & \text { untuk }\end{array}$
menggeneralisasi suatu permasalahan yang real ke abstrak untuk mempermudah masalah-masalah yang sulit dengan menggunakan huruf-huruf untuk mewakili bilangan yang diketahui dalam perhitungan. Namun, pada kenyataan di sekolah, sebagian besar siswa kesulitan mempelajari materi aljabar. Seperti yang diungkapkan Linsell (2008) bahwa aljabar tidak mudah dipahami oleh banyak siswa.

Walle (2008: 1) bahwa berpikir aljabar salah satunya melakukan generalisai dari pengalaman dan bilangan dan perhitungan, memformalisasikan ide-ide dengan penggunaan simbol yang berguna, dan mengeksplorasi konsep-konsep dari pola dan fungsi. Kriegler (2008:1), 
komponen dari berpikir aljabar adalah sebagai berikut.

1. Perkembangan alat berpikir matematika

Alat berpikir matematika merupakan kebiasaan berpikir yang meliputi keterampilan pemecahan masalah, kemampuan representasi, dan kemampuan penalaran kuantitatif.

2. Studi tentang ide dasar aljabar Ide dasar aljabar merupakan ranah dimana alat berpikir matematika berkembang yang meliputi aljabar sebagai generalisasi aritmetika, aljabar sebagai bahasa, dan aljabar sebagai alat untuk fungsi dan pemodelan matematika.

Pada umumnya kurikulum matematika sekolah memisahkan studi aritmetika dan aljabar. Aritmetika adalah fokus utama matematika sekolah dasar dan aljabar adalah fokus utama dari sekolah menengah sehingga hal ini mengakibatkan siswa sulit untuk mengubah dari aritmetika ke aljabar. Penyelesaian masalah berkaitan erat dengan kemampuan matematika siswa. Siswa dengan kemampuan matematika yang tinggi diharapkan menyelesaikan masalah aljabar dengan baik.

Disamping itu pembelajaran di MTs biasanya kelas dipisahkan berdasarkan gender. Hal ini dilakukan karena memang pada dasarnya agama islam memberikan aturan bahwa sebaiknya ketika siswa sudah mencapai usia baligh, siswa harus mulai dididik untuk tidak campur baur antara laki-laki dan perempuan. Sehingga hal ini juga harus menjadi perhatian guru khususnya guru MTs untuk memberikan materi berdasarkan perbedaan gender.

Berpikir aljabar memiliki keterkaitan dengan taksonomi SOLO karena taksonomi SOLO dapat digunakan sebagai alat untuk mengkategorikan berpikir aljabar siswa. Seperti penelitian yang dihasilkan Kamol (2005) yaitu mengenai kerangka berpikir aljabar siswa yang dikarakterisasikan berdasarkan taksonomi SOLO.

Dari rumusan masalah tersebut, tujuan penelitian adalah mendeskripsikan proses berpikir aljabar siswa kelas VIII berkemampuan matematika tinggi, sedang, dan rendah berkelamin laki laki dalam menyelesaikan soal aljabar menurut Taksonomi Solo dan mendeskripsikan proses berpikir aljabar siswa kelas VIII berkemampuan matematika tinggi, sedang, dan rendah berkelamin perempuan dalam menyelesaikan soal aljabar menurut Taksonomi Solo.

\section{METODE PENELITIAN}

Penelitian ini termasuk dalam jenis penelitian kualitatif, yaitu penelitian yang menggunakan data kualitatif kemudian dideskripsikan untuk menghasilkan paparan Proses Berpikir Aljabar Siswa MTs Kelas VIII Menurut Taksonomi Solo Ditinjau Dari Perbedaan Gender dengan kemampuan matematika tinggi. Data kualitatif pada penelitian ini adalah hasil jawaban siswa. Selain itu, dilaksanakan pula wawancara yang dilakukan peneliti terhadap subjek penelitian agar dapat mendeskripsikan secara detail mengenai proses berpikir siswa.

Calon subjek terdiri dari siswa kelas VIII MTs Miftahul Huda. Adapun penentuan subjek penelitian ini adalah tiga orang siswa perempuan yang berkemampuan tinggi, sedang dan rendah. Penggolongan siswa dalam ke tiga kelompok tersebut sesuai dengan informasi dari guru mata pelajaran matematika. 
Dalam penelitian ini, instrumen utama dalam pengumpulan data adalah peneliti sendiri. Instrumen pendukung dalam penelitian ini meliputi: Soal Aljabar yang digunakan dalam penelitian ini berisi soal-soal aljabar yang dirancang untuk mengetahui proses berpikir siswa. Disamping itu, penelitian ini membuat pedoman wawancara sebagai panduan untuk melakukan wawancara agar dalam pelaksanaannya tidak ada informasi yang terlewat. Pengumpulan data pada penelitian ini dilakukan dengan menggunakan dua teknik yaitu tes tertulis dan wawancara. Adapun teknik analisis data dalam penelitian ini meliputi: tahap reduksi data, menyajikan data dan menarik kesimpulan (Nafi'an, 2012). Prosedur penelitian yang dilaksanakan dalam penelitian ini meliputi tiga tahap yaitu tahap persiapan, tahap pelaksanaan dan tahap penyelesaian.

\section{HASIL PENELITIAN DAN PEMBAHASAN}

Tujuan dari penelitian ini adalah mendiskripsikan proses berfikir aljabar siswa dalam menyelesaikan masalah aljabar berdasarkan taksonomi SOLO dilihat dari perbedaan gender. Berikut adalah data hasil penelitian

1. Siswa Perempuan

1.a. Komponen Pola

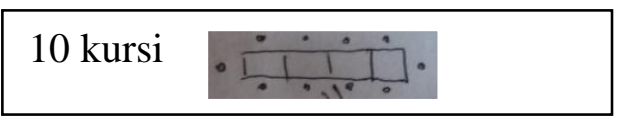

Gambar 1. Poin a

Jawaban siswa perempuan pada poin a ditunjukkan seperti pada gambar 1 .

Gambar 1 tersebut menunjukkan bahwa siswa perempuan menyelesaikan soal pada poin a dengan cara membuat gambar seperti susunan pada soal. Dari hasil tersebut maka siswa perempuan dalam menyelesaikan soal pada level unistructural.

$$
30 \times 2+2=60+2=62
$$

$$
\text { Gambar 2. Poin b }
$$

Gambar 2 tersebut menunjukkan bahwa siswa perempuan menemukan suatu aturan dalam menjawab soal poin $b$ dengan cara mengidentifikasi susunan model gambar kemudian mentransformasikannya ke dalam konsep matematika khususnya konsep perkalian dan penjumlahan. Dari hasil tersebut maka siswa perempuan dalam menyelesaikan soal pada level multistructural

$$
\begin{gathered}
X \times 2+2 \\
X \times 2+2 \\
2 X-2
\end{gathered}
$$

\section{Gambar 3. Poin c}

Gambar 3 tersebut menunjukkan bahwa siswa dapat menggeneralisasikan pola yang diberikan dengan cara mengenali pola bilangan kemudian mentransformasikannya ke dalam konsep matematika khususnya konsep perkalian dan penjumlahan. Dari hasil tersebut maka siswa perempuan dengan kemampuan tinggi dalam menyelesaikan soal pada level relational 
1 baris pola di lantai terdapat 8 kelereng 2 baris pola di lantai terdapat 12 kelereng 3 baris pola di lantai terdapat 16 kelereng Berapa banyak kelereng pada pola lantai ke 4 ?

Pola $4=4 \times 4+4$

$$
\begin{aligned}
& =16+4 \\
& =20
\end{aligned}
$$

\section{Gambar 4. Poin d}

Gambar 4 tersebut menunjukkan bahwa siswa dapat membuat soal berkaitan pola yang pola tersebut di luar pengetahuan yang diasumsikan kemudian menggeneralisasikan pola bilangan tersebut. Dari hasil tersebut maka siswa perempuan dalam menyelesaikan soal pada level extended abstract

\section{1.b. Komponen Variabel}

Ketika $\mathrm{n}<6$, maka hasilnya $\mathrm{n}+6>\mathrm{n}+\mathrm{n}$ Ketika $n>6$, maka hasilnya $n+6<n+n$ Ketika $n=6$, maka hasilnya $n+6=n+n$

\section{Gambar 5. Poin a}

Gambar 5 tersebut menunjukkan bahwa siswa dapat mensubtitusikan satu bilangan percobaan kedalam bentuk aljabar, baik persamaan dan pertidaksamaan. Dari hasil tersebut maka siswa perempuan dengan kemampuan tinggi dalam menyelesaikan soal pada level unistructural

Jika $\mathrm{b}+\mathrm{d}=18$ dan $\mathrm{d}<5$, maka $\mathrm{b}>14$

Gambar 6. Poin b

Gambar 6 tersebut menunjukkan bahwa siswa mensubstitusikan beberapa bilangan ke dalam bentuk aljabar, pertidaksamaan dan persamaan yang diberikan. Dari hasil tersebut maka siswa perempuan dalam menyelesaikan soal pada level multistructural

Jika $\mathrm{b}+\mathrm{d}=18$ dan $\mathrm{b}<\mathrm{d}$, maka $\mathrm{b}<8$

\section{Gambar 7. Poin c}

Gambar 7 tersebut menunjukkan bahwa level relational dengan cara membuat hubungan diantara hasil bilangan yang telah disubstitusikan ke dalam bentuk aljabar, pertidaksamaan dan persamaan yang diberikan.

2. Siswa Laki-laki 2.a. Komponen Pola

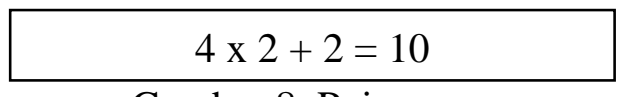
Gambar 8. Poin a

Gambar 8 tersebut menunjukkan bahwa siswa laki laki langsung dapat menemukan suatu aturan dalam menjawab soal poin a dengan cara mengidentifikasi susunan model gambar kemudian mentransformasikannya ke dalam konsep matematika khususnya konsep perkalian dan penjumlahan. Dari hasil tersebut maka siswa laki laki dalam menyelesaikan soal pada level multistructural

$$
30 \times 2+2=62
$$

Gambar 9. Poin b

Gambar 9 tersebut menunjukkan bahwa siswa laki laki menerapkan pola yang sama dengan pekerjaan pada poin a dengan menemukan 
suatu aturan dan mengidentifikasi susunan model gambar kemudian mentransformasikannya ke dalam konsep matematika khususnya konsep perkalian dan penjumlahan. Dari hasil tersebut maka siswa perempuan dengan kemampuan tinggi dalam menyelesaikan soal pada level multistructural

$$
\text { x. } 2+2=x^{2}+2=2 x^{2}
$$

Gambar 10. Poin c

Gambar 10 tersebut menunjukkan bahwa siswa dapat menggeneralisasikan pola tetapi terdapat kesalahan konsep matematika pada hasil akhir khususnya konsep perkalian dan penjumlahan aljabar. Dari hasil tersebut maka siswa laki laki dalam menyelesaikan soal pada level relational

Berapa banyak kursi untuk susunan 15 meja? $15 \times 2+2=32$

\section{Gambar 11. Poin d}

Gambar 11 tersebut menunjukkan bahwa siswa tidak paham dengan perintah soal. Disamping itu siswa juga tidak dapat membuat soal lain. Siswa hanya membuat soal yang berhubungan dengan soal pada poin a. Dari hasil tersebut maka siswa laki laki dalam menyelesaikan soal pada level prestructural

2.b. Komponen Variabel

$$
n+6
$$

Gambar 12. Poin a
Gambar 12 tersebut menunjukkan bahwa siswa laki laki tidak dapat memahami pertanyaan dari poin a pada komponen pola sehingga siswa laki laki dalam menyelesaikan soal pada level prestructural

$$
\text { b lebih besar dari pada d }
$$

Gambar 13 Poin b

Gambar 13 tersebut menunjukkan bahwa siswa tidak dapat menjelaskan darimana jawaban itu didapat karena tidak memahami soal. Dari hasil tersebut maka siswa laki laki dalam menyelesaikan soal pada level prestructural

$\mathrm{b}<\mathrm{d}$

Gambar 14. Poin c

Gambar 7 tersebut menunjukkan bahwa siswa tidak dapat menjelaskan darimana jawaban itu didapat karena tidak memahami soal. Dari hasil tersebut maka siswa laki laki dalam menyelesaikan soal pada level prestructural.

Berdasarkan hasil penelitian yang telah dilakukan akan dilakukan pembahasan

1. Komponen pola

Siswa perempuan menemukan suatu suku dari suatu pola dengan cara menggambar susunan model gambar kemudian mentransformasikan ke dalam konsep matematika, menggeneralisasikan pola yang diberikan dengan cara mengenali pola bilangan kemudian mentransformasikannya ke dalam konsep matematika, serta membuat soal yang berkaitan dengan pola 
tetapi pola yang dibuat berbeda dengan pola yang ada pada soal kemudian membuat generalisasi pola tersebut. Dengan demikian siswa perempuan dapat membuat soal yang berkaitan dengan pola di luar pengetahuan yang diasumsikan dan kemudian menggeneralisasikan pola tersebut. Berdasarkan penjelasan tersebut, respons yang diberikan siswa perempuan cenderung ke level relational dan extended abstract berdasarkan taksonomi SOLO.

Hal ini sesuai dengan pendapat Jamil (2017) Siswa dengan kemampuan berpikir aljabar pada level relational dalam menyelesaikan masalah aljabar berdasarkan taksonomi SOLO siswa mengintegrasikan semua aspek informasi yang diberikan satu sama lain menjadi struktur yang koheren.

Selanjutnya, Appulembang (2017) Subjek dapat membuat hubungan antar fakta serta dapat membangun sebuah teori/prinsip baru untuk menjawab soal dan dapat diselesaikan dalam waktu yang singkat.

Siswa laki laki menemukan suatu suku dari suatu pola dengan cara menentukan hubungan antara pola satu dan pola lain dan menuangkannya dalam bentuk kalimat matematis. Pada poin tersebut respons yang diberikan ini mencapai level multistructural berdasarkan taksonomi SOLO. Disamping itu siswa laki laki dapat menggeneralisasikan pola tetapi pada hasil akhir terdapat kesalahan konsep matematika khususnya konsep perkalian dan penjumlahan aljabar. Siswa laki laki juga tidak dapat membuat soal lain. Sehingga pada poin membuat soal siswa perempuan dengan kemampuan sedang hanya mencapai level prestructural.

2. Komponen Variabel

Berpikir aljabar siswa perempuan dalam menyelesaikan masalah pada komponen pola yaitu memahami peran variabel sebagai bilangan yang diperumum pada bentuk aljabar dengan menentukan suatu bilangan yang dapat dijadikan perwakilan dan memahami peran variabel sebagai bilangan yang diperumum pada persamaan dan pertidaksamaan dengan menentukan bilangan yang berlaku pada pertidaksamaan yang diberikan kemudian mensubstitusikannya ke dalam suatu persamaan yang ada sehingga menghasilkan kesimpulan dengan alasan yang logis.Dengan demikian dikatakan siswa kemampuan matematika tinggi dapat memberikan hubungan diantara beberapa informasi yang diberikan sehingga respons yang diberikan cenderung ke level relational berdasarkan taksonomi SOLO.

Berpikir aljabar siswa laki laki dalam menyelesaikan masalah pada komponen variabel yaitu siswa tidak memahami peran variabel sebagai bilangan yang diperumum pada bentuk aljabar, persamaan dan pertidaksamaan. Respons yang diberikan hanya mencapai level prestructural berdasarkan taksonomi SOLO. Hal ini didukung oleh pendapat Manibuy (2014) bahwa siswa pada tingkat prastruktural belum memahami soal yang diberikan sehingga cenderung tidak memberikan jawaban. 


\section{KESIMPULAN DAN SARAN}

Berikut kesimpulan yang ditarik pada penelitian ini

1. Proses berpikir siswa perempuan

a. Berpikir aljabar siswa perempuan dalam menyelesaikan masalah pada komponen pola cenderung pada level relational dan level extended abstract

b. Berpikir aljabar siswa perempuan dalam menyelesaikan masalah pada komponen variabel mencapai level relational dengan cara membuat hubungan diantara hasil bilangan yang telah disubstitusikan ke dalam bentuk aljabar, pertidaksamaan dan persamaan yang diberikan.

2. Proses berpikir siswa laki laki

a. Siswa laki laki dalam menyelesaikan soal pada komponen pola mencapai level multistructural dan relational berdasarkan taksonomi SOLO. Saat mengoperasikan bentuk aljabar pada komponen pola, siswa laki laki membuat kesalahan pada perhitungan hasil akhir. Siswa laki laki juga tidak dapat merespon ketika diminta untuk membuat soal. Sehingga pada poin membuat soal siswa laki laki dengan kemampuan sedang hanya mencapai level prestructural.

b. Berpikir aljabar siswa laki laki dalam menyelesaikan masalah pada komponen variabel yaitu siswa tidak memahami peran variabel sebagai bilangan yang diperumum pada bentuk aljabar, persamaan dan pertidaksamaan karena hanya menggunakan satu bilangan tertentu untuk menyelesaikan masalah yang dihadapi sehingga dikatakan respons yang diberikan hanya mencapai level prestructural berdasarkan taksonomi SOLO.

Berdasarkan kesimpulan hasil penelitian di atas, beberapa saran yang dapat dikemukakan adalah sebagai berikut.

1. Siswa perempuan disarankan untuk diberikan soal mengenai pola dan variabel dengan tingkat kesulitan yang lebih tinggi agar berpikir aljabar siswa lebih baik lagi.

2. Siswa laki laki dapat diberikan bimbingan dalam menemukan suku tertentu dan operasi aljabar, serta perlu diberikan bimbingan juga mengenai pengertian variabel.

\section{DAFTAR PUSTAKA}

Appulembang, O. D. (2017). Profil Pemecahan Masalah Aljabar Berpandu pada Taksonomi Solo Ditinjau dari Gaya Kognitif Konseptual Tempo Siswa SMA Negeri 1 Makale Tana Toraja. Journal of Language, Literature, Culture, and Education POLYGLOT Vol. 13 No. 2 Juli 2017

Jamil, A. F. (2017). Peningkatan Level Berpikir Aljabar Siswa Berdasarkan Taksonomi SOLO Pada Materi Persamaan Linier Melalui Pemberian Scaffolding. JIME, Vol. 3. No. 1 ISSN 24429511.

Kamol, N. (2005). "A Framework in Characterizing Lower Secondary School Students' Algebraic Thinking". Doctoral Dissertation, Srinakharinwirot University. 
Kriegler, S. (2008). Just What is Algebraic Thinking? Submitted for Algebraic Concepts in the Middle School A special edition of Mathematics Teaching in the Middle School. Online. (http://www.mathandteaching.org/ mathlinks/downloads/articles-01kriegler.pdf, diakses tanggal 7 Desember 2016).

Linsell, C. (2008). Early Algebraic Thinking: Links to Numeracy. Wellington, New Zealand: TLRI website (www.tlri.org.nz)

Manibuy, R., dkk. (2014). Analisis Kesalahan Siswa dalam Menyelesaikan Soal Persamaan Kuadrat Berdasarkan Taksonomi SOLO pada Kelas X SMA Negeri 1 Plus di Kabupaten NabirePapua. Jurnal Elektronik Pembelajaran Matematika Vol. 2, No. 9, hal 933-945

Nafi'an, I. M. (2012). Proses Berpikir Siswa Kelas V Dalam Menyelesaikan Soal Cerita Pada Pokok Bahasan Pecahan Di Sekolah Dasar Khadijah Surabaya. Gramatika Vol. I No.2, 115-119.

Saefudin, A.A. (2011). Analisis Proses Berpikir Siswa Kelas V Sekolah Dasar yang telah Mengimplementasikan

Pendekatan Matematika Realistik Indonesia (PMRI) dalam pemecahan Masalah Matematika Materi Pokok Bilangan Cacah. Tesis. Surakarta: Program Pasca Sarjana Universitas

Sebelas Maret Surakarta.

Susandi, A. D., \& Widyawati, S. (2017). Proses Berpikir Dalam Memecahkan Masalah Logika Matematika Ditinjau Dari Gaya Kognitif Fiel Independent Dan Fiel Dependent. Jurnal Matematika dan
Pendidikan Matematika Vol. 1 No. 1, 93-112.

Walle, V.D. 2008. Elementary and Middle School Mathematics, sixth Edition, Terjemahan Suyono. Jakarta, Erlangga. 